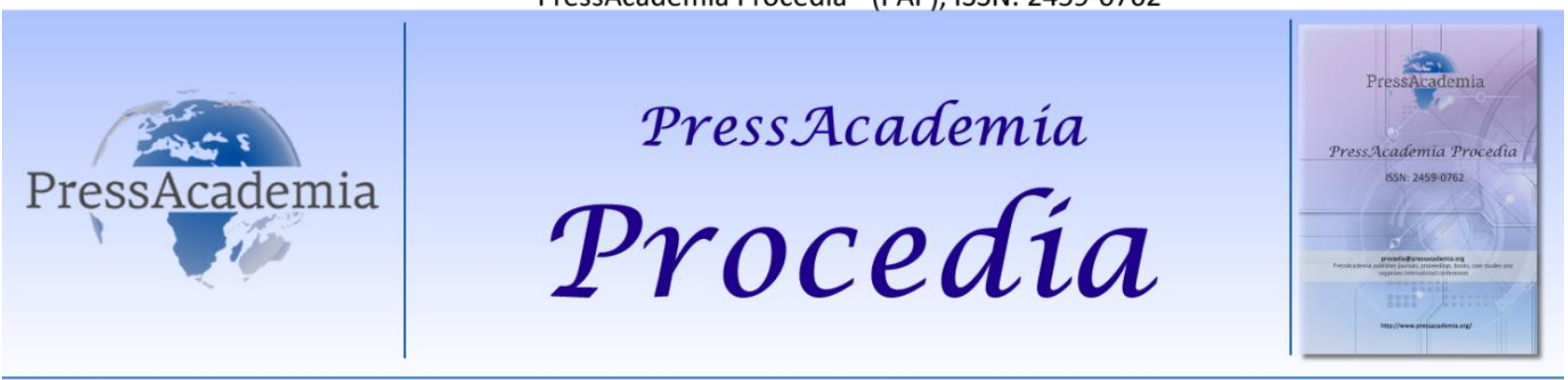

Global Business Research Congress (GBRC), May 24-25, 2017, Istanbul, Turkey.

\title{
THE RELATIONSHIPS BETWEEN CONSUMER ATTITUDES TO THE COMPLAINT AND SWITCHING COST: A STUDY ON BANKING INDUSTRY
}

DOI: 10.17261/Pressacademia.2017.410

PAP-GBRC-V.3-2017(25)-p.246-256

Volkan Ozbek ${ }^{1}$, Sule Sahin ${ }^{2}$, M. Emin Akkilic ${ }^{3}$, Fatih Koc $^{4}$

${ }^{1}$ Balıkesir Üniversitesi, Burhaniye UBYO, Uluslararası Ticaret Bölümü, Balıkesir, Turkey. vozbek@balikesir.edu.tr

${ }^{2}$ Balıkesir Üniversitesi, SBE, Uluslararası Ticaret ve Pazarlama Bölümü, Balıkesir, Turkey. sule-91-sahin@hotmail.com

${ }^{3}$ Balıkesir Üniversitesi, Burhaniye UBYO, Uluslararası Ticaret Bölümü, Balıkesir, Turkey. eakkilic@balikesir.edu.tr

${ }^{4}$ Kocaeli Üniversitesi, Kandıra UBYO, Dış Ticaret ve Avrupa Birliği Bölümü, Kocaeli, Turkey. fatih.koc@kocaeli.edu.tr

To cite this document

Ozbek, V., Şahin, Ş., Akkılıç, M.E., Koç, F. (2017). The relationships between consumer attitudes to the complaint and switching cost: a study on banking industry, PressAcademia Procedia (PAP), V.3, p.246-256.

Permemant link to this document: $\underline{\mathrm{http}}: / /$ doi.org/10.17261/Pressacademia.2017.410

Copyright: Published by PressAcademia and limited licenced re-use rights only.

\begin{abstract}
It could be considered that switching cost will be decreased when compliant attitude toward a firm or products of a firm increased. From this point of view, the main aim of this study is to reveal possible effects of bank customers' attitudes towards complaint on switching cost. In the scope of the study, attitudes toward complaint examined as two dimensions, and switching cost as five dimensions. The data of the research was gathered in the scope of a field study performed with survey method that implemented on 340 participants determined with convenience sampling among bank customers in Saruhanlı district of Manisa. As a result of data analysis, it is determined that personal complaints as a dimension of attitudes toward complaint has a negative effect on four dimensions of switching cost (financial, uncertainty, learning, and relational costs) except setup cost. In addition, it is identified that social complaints, another dimension of attitudes toward compliant, has negative effect on four dimensions of switching cost except financial cost. With the increase in attitude to the complaint, switching cost is decreasing. Therefore, the intention of consumers to change the firm will increase. The study was concluded with some suggestions to academicians and practitioners.
\end{abstract}

Keywords: Consumer attitudes to the complaint, switching cost, banking industry.

JEL Codes: G20, M30, M31

\section{ŞiKÂYETE YÖNELIK TUTUM VE DEĞiŞTiRME MALIYETi iLiŞKISi: BANKACILIK SEKTÖRÜNDE BíR UYGULAMA}

\section{ÖZET}

İşletmeye ya da işletme ürünlerine yönelik şikâyet tutumu arttıkça değiștirme maliyetinin azalacağı düşünülebilir. Bu noktadan hareketle bu araştırmanın temel amacı, banka müşterilerinin şikâyete yönelik tutumlarının değiştirme maliyeti üzerindeki olası etkilerini ortaya koymaktır. Araştırma kapsamında şikâyete yönelik tutum 2 boyut, değiştirme maliyeti ise 5 boyut olarak incelenmiştir. Araştırma verileri, Manisa'nın Saruhanlı ilçesindeki banka müşterileri arasından kolayda örnekleme yöntemiyle belirlenen 340 tüketici üzerinde anket yöntemiyle yürütülen saha çalışması kapsamında toplanmıştır. Verilerin analizi sonucunda, şikâyete yönelik tutumun boyutu olan kişisel şikâyetlerin değiştirme maliyetinin kurulum maliyeti dışında kalan 4 boyutu üzerinde (parasal, belirsizlik, öğrenme ve ilişkisel maliyet) negatif etkisinin olduğu tespit edilmiştir. Bununla birlikte, şikâyete yönelik tutumun diğer boyutu olan sosyal şikâyetlerin değiştirme maliyetinin parasal maliyet dışında kalan 4 boyutu üzerinde negatif etkisi bulunmuştur. Tüketicilerin şikâyete yönelik tutumu arttıkça değiştirme maliyeti azalmaktadır. Dolayısıyla, tüketicilerin firmayı değiştirme niyeti artacaktır. Çalışma, akademisyenlere ve uygulayıcılara önerilerde bulunularak tamamlanmıştır.

Anahtar Kelimeler: Şikayete yönelik tutum, değiştirme maliyeti, bankacılık sektörü. JEL Kodları: G20, M30, M31 


\section{GiRiş}

Günümüzde tüketicinin bilinçlenmesi, teknolojinin gelişmesi, ürün çeşitliliğinin artması gibi nedenler, müşterilerin ihtiyaç, istek ve beklentilerinin sürekli değişmesine ve müşterinin ürün hakkındaki değerlendirmelerinin farklılaşmasına yol açmaktadır. Bu nedenle müşterilerin şikâyetlerinin değişiklik göstermesi olasıdır. Öyle ki, bir müşteri ilk defa satın aldığı bir üründen memnunken, ikinci defa satın aldığı aynı üründen memnun olmayıp şikâyet davranışı sergileyebilir. Birey, bu şikâyetlerini kişisel ya da sosyal bir etkileşimle başkalarıyla paylaşabilir. Örneğin bir müşteri, yakın çevresindeki insanlara kişisel şikâyet tutumuna konu olan durumu anlatabilir ya da tüketici dernekleri ve tüketici mahkemeleri gibi yasal kurumlara başvurarak sosyal şikâyet davranışı sergileyebilir. Bu bağlamda, müşteri şikâyet davranışlarının sürekli takip edilmesi ve şikâyetlerin nedenlerinin araştırılması, işletmelere uzun vadede müşteri güveni, müşteri memnuniyeti ve sadık müşteriler gibi bazı avantajlar sağlayacaktır. Şikâyete konu olan sorun, işletme tarafından çözüldüğünde müşteri memnuniyeti artabilirken, çözülmediğinde ise müşterinin firmayı değiştirmesine kadar gidebilecek kötü sonuçlar doğurabilmektedir. Bu durumda değiştirme maliyeti kavramı öne çıkmaktadır. Değiştirme maliyeti genel bir ifade ile bir müşterinin kullandığı ürün ya da firmayı değiştirmeyi düşünmesiyle katlanmayı göze aldığı maliyetleri ifade etmektedir.

Müşteri, şikâyet etme güdüsünü harekete geçirecek bir sorunla karşılaştığında, onun söz konusu firmayı, markayı ya da ürünü değiştirmesi beklenebilir. Ancak bu değişiklik maliyetli olacaksa, yani değiştirme maliyeti yüksekse, müşteri değişiklik tercihini erteleyebilecektir. Bununla birlikte, şikâyete yönelik tutumun artmasıyla, firmanın ürünlerini değiştirme maliyetinin de azalacă̆ı; dolayısıyla müşterinin bu firmayı daha kolay değiştirebileceği de beklenebilir. Ancak, doğrudan bu bulguyu ortaya koyan bir araştırmaya literatür araştırması sürecinde rastlanmamıştır. Literatürdeki bu eksikliği gidermek hedefiyle, bu araştırmanın amacı, şikâyete yönelik tutumun değiştirme maliyeti üzerindeki olası etkisini ortaya koymak şeklinde belirlenmiştir.

\section{LITERATÜR ARAŞTIRMASI}

\section{1. Şikâyete Yönelik Tutum}

Müşterilerin giderek bilinçlenmesiyle artış gösteren şikâyet davranışları, gerek işletmelerin gerekse pazarlama alanındaki akademisyenlerin en çok önem verdiği konulardan biri haline gelmiştir. Özellikle insan faktörü sebebiyle hataların sıklıkla gerçekleştiği hizmet sektöründe, müşteriler sorunlar karşısında farklı tutumlar sergileyebilmektedir (Eşkinat, 2009, s.209). Söz konusu tutumların belirlenmek istenmesinin en önemli nedeni, müşteri şikâyetlerinin değerlendirilmesi veya dikkate alınmasının işletme karlılığı ve hizmet kalitesini arttıracağı düşüncesidir (Burucuoğlu, 2011, s.64).

Müşteri şikâyeti; müşterinin bir ürünü satın almadan önceki beklentileri ve satın aldıktan sonraki deneyimlerinin olumsuz sonuçlanması halinde, bizzat işletmeye ya da hukuksal bir kuruluşa yaptığı yazılı veya sözlü beyanı olarak ifade edilmektedir (Jacoby ve Jaccard, 1981, s.6). Lovelock ve arkadaşları (1999) bu kavramı, yaşanan olumsuz tecrübeyi bir şahsa, işletmeye ya da resmi bir kuruma iletmek olarak tanımlamaktadır. Eşkinat (2009) ise şikâyet bildiriminde bulunanların sadece müşteriler olmadığını, çevre dernekleri, sivil toplum kuruluşları gibi kurumların da şikâyet bildiriminde bulunabileceğini dile getirmiştir.

Bu tanımlamalardan yola çıkarak, müşteri şikâyeti "kişilerin ya da kurumların bir firma, marka ya da üründen memnun kalmadığında üreticilere, bu konuda düzenleme yapan kurumlara (tüketici hakları dernekleri ve ilgili mahkemeler gibi) ve gerçek ya da sanal çevredeki kişilere bu durumu duyurması ya da durumla ilgili bir düzenleme yapılmasını talep etmesi şeklinde gerçekleşen bir davranıştır" şeklinde tanımlanabilir.

Müşteri şikâyetleri konusunda son yıllarda yapılan çalışmalar irdelendiğinde şikâyet yönetiminin etkinliğinden sıklıkla bahsedildiği görülmektedir. Şikâyet yönetiminde işletmelerin müşteri şikâyetlerine önem vermesi gerekliliğinden ya da şikâyet yönetim standartlarının oluşmasının öneminden bahsedilmektedir (Sarı, 2008, s.5; Şensöz, 2010, s.2). Fakat burada üzerinde durulması gereken noktalardan biri, müşterilerin şikâyet tutum ve davranışlarının nasıl şekillendiğinin belirlenmesidir. Yani, bir müşterinin memnuniyetsizlik karşında nasıl bir tepki gösterdiği bilinmelidir. Hirschman'ın (1970) memnuniyetsizlik yaşayan müşterinin tepkilerini gruplandırdığı bir çalışmada, şikâyet eden müşteriler bildirimde bulunanlar ve bulunmayanlar olarak ikiye ayrılmıştır. Benzer şekilde Day ve London (1977) memnuniyetsizlik yaşayan müşterilerin davranışlarını, eylemde bulunma ve bulunmama olmak üzere sınıflandırmıştır. Crie'ye göre (2003) ise şikâyet tutumu olan müşteri ya davranışsal ya da davranışsal olmayan bir tepki verir. Davranışsal müşteri tepkisi, yalnızca üretici/satıcı firmaya değil aynı zamanda sektöre/pazara karşı da ortaya çıkabilir. Davranışsal olmayan tepki ile müşteri şikâyet davranışında bulunmaz; tekrar aynı ürün ya da hizmet sağlayıcıyı tercih eder veya hiçbir şey olmamış gibi davranışsal sadakatle açıklanabilecek davranışlar sergiler (Crie, 2003, s.61).

\subsection{Değiştirme Maliyeti}

Porter’a göre (2007) değiştirme maliyeti, müşterinin bir ürün sağlayıcıdan diğerine geçişinde maruz kalacağı tek seferlik maliyet olarak tanımlanmaktadır. Sharma ve Patterson (2000) değiştirme maliyetini "mevcut ilişkiyi sona erdirmek ve alternatif sağlamak için gereken ek maliyetlerin büyüklüğünün algılanması" olarak ifade etmektedir. Klemperer (1995) ise bu kavramın, bir müşterinin mevcut satın alımıyla önceki satın alımını kıyaslamasından dolayı ortaya çıktığını söylemektedir. 
Yani bir müşteri, şikâyete konu olan bir durumla karşılaştığında rakip ürünleri ya da firmaları ihtiyaç hissettiği alanlarda kıyaslamaktadır. Bu durumda, müşteri mevcut ürünü değiştirmeyi düşünecektir (Zeithaml vd. 1996, s.34).

Alternatif ürün ya da firmaların çok olduğu ve tedarikçi değiştirme maliyetinin düşük olduğu rekabetçi piyasalarda, nispeten daha yüksek müşteri memnuniyeti bile müşteri kayıplarının önüne geçememektedir. Örneğin bakkal dükkânı, restoran, banka gibi hizmet sağlayıcılardan yararlanan müşteriler, tamamı ile memnun olmadıkları takdirde çabucak kaçabilmektedir (Şimşek ve Noyan, 2009, s.123). Ancak sunulan hizmetin parasal olarak değerlendirilmesinin zor olduğu, sağlık hizmetleri, yönetim danışmanlığı ve hukuk hizmetleri alanında değiştirme maliyeti daha yüksektir (Aydın, 2005, s.30). Örneğin, Türkiye'de bankaların fazla olması, müşterilerin kolayca başka bankaya geçmesini sağlayacaktır. Fakat GSM sektöründe az sayıda firma olduğu için, firmalar müşterilerini kaybetmek istemeyeceklerinden değiştirme maliyetlerini yüksek tutacaklardır. Diğer yandan, değiştirme maliyetlerini düşük tutan bir firma zaman içerisinde farklı firmalarla rekabet eder duruma gelecek ve müşteri kaybedecektir (Klemperer, 1995, s.527). Özetle, işletmeler değiştirme maliyetlerini etkin ve verimli bir şekilde değerlendirdiğinde, sektörde avantaj sağlayabilecek ve müşterilerinin rakip firmalara kaymasını önleyebilecektir.

Değiştirme maliyeti konusunda yapılan çalışmaların temeli 1980'li yıllara dayanmaktadır. Ancak ilgili literatür incelendiğinde, değiştirme maliyeti kavramı ve bu kavramın sınıflandırılması hakkında ortak bir paydada buluşulamadığı görülmektedir. Çünkü bu kavram, parasal maliyetin yanında psikolojik, ekonomik ve fiziksel maliyetlerden (Jackson, 1985), öğrenme maliyetinden (Klemperer, 1995) ve prosedürel maliyetler (Jones vd. 2002) gibi birçok maliyetten oluşmaktadır. Bu noktada, Klemperer'in (1995) işlem, öğrenme ve anlaşmaya dayalı (sözleşmeye dayalı) maliyet sınıflandırması literatürde temel sınıflandırma olarak ele alınmaktadır. Guiltinan (1989) ise kurulum, risk ve psikolojik maliyetlerden bahsetmektedir. Lee ve Cunnigham (2011) ise değiştirme maliyetini, prosedürel, ilişkisel ve finansal maliyet olarak sınıflandırmaktadır. Literatürde yapılan sınıflandırmaların tümünü kapsayan genel bir sınıflandırma yapılmasını gerekli gören Aydın (2005), değiştirme maliyetlerinin finansal, prosedürel ve psikolojik maliyetlerden oluştuğunu belirtmektedir. Bu çalışmada, finansal maliyetlerin parasal ve fayda kaybı maliyetlerinden, prosedürel maliyetlerin değerlendirme, kurulum ve öğrenme maliyetlerinden, psikolojik maliyetlerin ise ilişkisel ve belirsizlik maliyetlerinden oluştuğu ifade edilmektedir.

Finansal maliyet, bir müşterinin mevcut işletmeden vazgeçip yeni bir işletmeyi tercih etmesinin parasal maliyetinin yanı sıra, bu müşterinin mevcut işletmede var olan imkânları kaybetmesinden kaynaklanan maliyetleri kapsamaktadır (Özer ve Aydın, 2004, s.161). Finansal maliyetin boyutlarından biri olan parasal maliyet, bir mal veya hizmeti elde etmek ya da değiştirmek için müşterilerin katlandığı maddi maliyetlerdir (Lee ve Cunnigham, 2001, s.115). Bunlar faiz, komisyon veya para olabilir (Çankaya ve Çilingir, 2008, s.28). Örneğin, bir banka müşterisinin mevcut bankasından vazgeçip başka bir bankayı tercih ettiğinde yaşadığı maddi kayıplar parasal maliyettir. Finansal maliyetin diğer boyutu olan fayda kaybı maliyeti ise, firmayı değiştirme sonucunda, o firmadan elde edilen bazı faydaların ortadan kalkmasıyla ortaya çıkan maliyettir.

Prosedürel değiştirme maliyeti, tüketicinin satın alma sürecinin neden olduğu zaman ve çaba gerektiren işlemlerden kaynaklanan maliyet algısıdır (Özer ve Aydın, 2004, s.161). Prosedürel maliyetin ilk boyutu olan değerlendirme maliyeti, müşterinin değişim esnasında diğer firmaları değerlendirirken ortaya çıkan zaman kaybı ve harcanan çabadır. Kurulum maliyeti, müşterinin kullandığı firmayı değiştirmesiyle ortaya çıkan kuruluş maliyetleridir. Örneğin, bankasını değiştiren bir müşteri, yeni bankasındaki hesap bilgilerini ve şifreleri öğrenmek zorunda kalacaktır. Öğrenme maliyeti ise, bir markada önceden öğrenilen özellikler, tercih edilen diğer markada kullanılamıyorsa ya da nasıl kullanıldığının öğrenilmesi zaman kaybına neden oluyorsa ortaya çıkar (Jones, vd. 2002, s.262). Bu tanıma göre öğrenme maliyetine, müşterinin yeni tercih ettiği bankanın internet bankacılı̆ındaki fonksiyonları ve yapabileceği işlemleri öğrenmesi örnek verilebilir.

Psikolojik maliyet, genel olarak müşterinin bir ürün satın almadan önce veya satın aldıktan sonra bilişsel olarak taşıdığı endişeden kaynaklanan maliyeti ifade eder. Bu bağlamda psikolojik maliyette, müşterinin ürün satın aldıktan sonra ürünle ilgili ihtiyacı giderme/gidermeme, beğenme/beğenmeme gibi bilişsel maliyetler vardır. Bu maliyetler, hizmetin sağladığı fayda ve personelin ilgisi gibi duygusal faydalardan çıkarılmaktadır (Erdoğan ve Torun, 2009, s. 51). Psikolojik maliyetin ilk boyutu olan ilişkisel maliyet (batık maliyet) kavramı, müşterinin ürün ya da firma ile sürekli münasebetinden doğan güvenini kaybetmesi olarak tanımlanmaktadır (Jones, vd. 2002, s.262). Eğer firma, müşterinin bu konudaki özverisini azaltırsa, ilişkisel maliyet azalır ve müşteri performansı (şikâyete yönelik tutum veya davranış) artar (Karaca, 2010, s.450). Böylece, müşteri farklı ürün ya da firma arayışına girer ve müşteri/firma ya da müşteri/personel ilişkisinden kaynaklanan ilişkisel maliyet ortaya çıkar (Aydın, 2005, s.40; Karaca, 2010, s.450). Psikolojik maliyetin diğer boyutu olan belirsizlik maliyeti ise, tüketicinin iyi bildiği bir firmayı değiştirmeyi düşünmesiyle oluşan endişe ya da risk olarak ifade edilmektedir (Klemperer,1995, s.517; Jones vd. 2002, s.261; Lee ve Cunnigham, 2001, s.116; Aydın, 2005, s.41). Bu maliyet, müşterinin algıladığı belirsizlik sona erene kadar devam eder. Örneğin, müşteri sürekli kullandığı bankayı değiştirmek istemesiyle birlikte, tercih edeceği bankanın avantaj ve dezavantajlarını düşünür ve bu durumda strese girer. Risk alma, çeşitli maliyetlere katlanma gibi durumları değerlendirir. Dolayısıyla, müşteri yeni bir bankaya geçtikten sonra bile beklentileri karşılanıncaya kadar belirsizlik maliyeti algılamaya devam edecektir. 


\section{3. Şikâyete Yönelik Tutum ve Değiştirme Maliyeti Arasındaki İlişkiler}

Müşteri ile firma arasındaki ilişkide problemlerin olması kaçınılmazdır. Ancak asıl sorun, müşterilerin sorunları telafi edilmediğinde ya da şikâyet tutumları firma tarafından dikkate alınmadığında ortaya çıkar. Çünkü müşteriler böyle durumlarda sorun yaşadığı firmayı ya da ürünü değiştirmeyi düşünebilecektir. Bu nedenle, şikâyete yönelik tutumların değiştirme maliyeti üzerinde negatif bir etkisi beklenir. Literatürde bu konuda doğrudan yapılmış bir araştırmaya rastlanmamış olsa da dolaylı yoldan bu duruma işaret eden bazı çalışmalar bulunmaktadır. Örneğin, Zeithaml ve arkadaşları (1996) yürüttükleri bir çalışmada, müşterilerin olumsuz davranışsal niyetlerinin (müşterilerin şikâyetlerini arkadaşlarına, çevresine ya da yasal bir kuruma iletmesi) şirketlerle yaptığı iş miktarını azalttığını ifade etmiştir.

Müşterilerin şikâyet davranışlarının belirlenmesine yönelik çalışmasında Singh (1988), müşterilerin şikâyet tutumlarının üç şekilde gerçekleştiğini ifade etmiştir. Birincisi, sesli yanıt (satıcıdan düzeltme arama), ikincisi özel yanıt (negatif ağızdan ağıza iletişim) ve sonuncusu ise üçüncü şahıslara yönelik şikâyettir. Benzer şekilde Richins (1983) de şikâyet etme davranışlarının kişisel faydalardan (kişinin öz doğası gereği şikâyet etme eğilimi) veya sosyal faydalardan (kişinin sosyal çevresinden etkilenmesi) oluşabileceğini ifade etmektedir. Bu çalışmalarda şikâyet eden müşterilerin değiştirme algısıyla ilgili olarak bilgi verilmese de şikâyet eden müşterilerin bazı değiştirme maliyetlerine katlanacağı düşünülmektedir. Koç, Şahin ve Özbek'in (2014) çalışmalarında hizmet hatalarındaki artışın müşterilerin hizmet kalitesi algılarını azaltacağı ortaya konmuştur. Bu noktada, hizmet hatalarındaki artışın şikâyete yönelik tutumu yükseltebileceği de düşünülebilir. Aynı şekilde, müşterilerin düşük hizmet kalitesi algıladıkları bir ürün ya da firmayı terk etmeleri, yani bu firmaya yönelik düşük değiştirme maliyetine sahip olmaları da beklenebilir.

Yılmaz ve Şen (2004) tarafından yapılan bir araştırmada, Eskişehir'de mahalle dükkânlarından alışveriş yapan müşterilerin şikâyetleri belirlenmeye çalışımıştır. Araştırma sonucunda, buradan alışveriş yapıldığında memnun olmayan müşterilerin yöneticiye şikâyet etme, yaşadıklarını çevrelerine anlatma ve ürün değiştirme eğiliminde bulundukları tespit edilmiştir. Şikâyetin değiştirme maliyetini negatif olarak etkilediği doğrudan söylenemese de bu araştırma, şikâyet eğilimi ile ürün değiştirme isteğinin bir arada değerlendirildiğini göstermesi bakımından önemlidir. Bozkaya (2012), bankacılık sektöründe hizmet hatası sonucunda oluşan müşteri davranışlarını ve hizmet hatasından kaynaklanan sebeplerin hangi değiştirme maliyetine daha çok etki ettiğini belirlemeye çalışmıştır. Araştırma sonucunda, hizmet hatası yaşayan müşterilerin yaşadığı olumsuz tecrübeyi yakın çevresiyle paylaştığı, ilgili bir kişiye şikâyette bulunduğu, kendilerinden özür dilense bile memnun olmadıkları ve kullandıkları bankayı değiştirdikleri tespit edilmiştir. Diğer yandan hizmet hatası yaşayan müşterilerin, en çok fayda kaybı maliyeti, daha sonra da sosyal maliyet algıladığı tespit edilmiştir.

Filip (2009), banka müşterilerinin daha az hizmet almalarına ve daha az ürün yelpazesiyle işlem yapmalarına rağmen, bankalarını değiştirme oranının düşük olduğunu ifade etmektedir. Bunun sebebi olarak, banka değiştirmede bürokratik işlemlerin (kurulum maliyeti) fazla olması gösterilmektedir. Benzer şekilde, Ruyter ve Wetzels (1998) değiştirme maliyetlerinin, hizmetlerde mallara göre daha yüksek olduğunu ve bankacılık gibi hizmet sektöründe faaliyet gösteren işletmelerde daha da önemli rol oynadığını ileri sürmüşlerdir. Bazı durumlarda müşteriler, bankanın sunduğu hizmetten memnun olmasalar bile değiştirme maliyetleri yüzünden aynı bankayı tercih etmeye devam etmek zorunda olduklarını ifade etmektedirler (Bozkaya, 2012, s.90).

Yukarıda ifade edilen araştırmalardan anlaşılacağı gibi, bilhassa rekabetin yoğun yaşandığı hizmet sektöründe şikâyet durumlarına rastlanmakta ve hizmet hatalarının firma değiştirmeye yol açabildiği dile getirilmektedir. Ancak şikâyete yönelik tutumların değiştirme maliyeti üzerindeki olası etkilerinin incelendiği herhangi bir çalışmaya literatür çalışması esnasında rastlanmamıştır. Dolayısıyla, bu çalışmanın literatüre katkı sağlayacağı düşünülmektedir.

Bu araştırmanın ön çalışması sürecinde fayda kaybı maliyeti ve değerlendirme maliyetinin diğer boyutlarla iç içe geçtiği görüldügünden, literatürde ifade edilen yedi boyuttan beşi araştırmanın ana çalışmasına dahil edilmiştir. Böylece, araştırma kapsamında aşağıdaki hipotezler belirlenmiştir.

H1: Şikâyete yönelik tutumun kişisel şikâyet boyutunun değiştirme maliyetinin parasal maliyet boyutu üzerinde negatif yönlü ve anlamlı bir etkisi vardır.

H2: Şikâyete yönelik tutumun kişisel şikâyet boyutunun değiştirme maliyetinin belirsizlik maliyeti boyutu üzerinde negatif yönlü ve anlamlı bir etkisi vardır.

H3: Şikâyete yönelik tutumun kişisel şikâyet boyutunun değiştirme maliyetinin öğrenme maliyeti boyutu üzerinde negatif yönlü ve anlamlı bir etkisi vardır.

H4: Şikâyete yönelik tutumun kişisel şikâyet boyutunun değiştirme maliyetinin kurulum maliyeti boyutu üzerinde negatif yönlü ve anlamlı bir etkisi vardır.

H5: Şikâyete yönelik tutumun kişisel şikâyet boyutunun değiştirme maliyetinin ilişkisel maliyet boyutu üzerinde negatif yönlü ve anlamlı bir etkisi vardır.

H6: Şikâyete yönelik tutumun sosyal şikâyet boyutunun değiştirme maliyetinin parasal maliyet boyutu üzerinde negatif yönlü ve anlamlı bir etkisi vardır. 
H7: Şikâyete yönelik tutumun sosyal şikâyet boyutunun değiştirme maliyetinin belirsizlik maliyeti boyutu üzerinde negatif yönlü ve anlamlı bir etkisi vardır.

H8: Şikâyete yönelik tutumun sosyal şikâyet boyutunun değiştirme maliyetinin öğrenme maliyeti boyutu üzerinde negatif yönlü ve anlamlı bir etkisi vardır.

H9: Şikâyete yönelik tutumun sosyal şikâyet boyutunun değiştirme maliyetinin kurulum maliyeti boyutu üzerinde negatif yönlü ve anlamlı bir etkisi vardır.

H10: Şikâyete yönelik tutumun sosyal şikâyet boyutunun değiştirme maliyetinin ilişkisel maliyet boyutu üzerinde negatif yönlü ve anlamlı bir etkisi vardır.

\section{YÖNTEM}

\subsection{Araştırmanın Modeli}

Araştırmanın amacına uygun olarak geliştirilen hipotezleri test etmek için, şikâyete yönelik tutumun iki boyutunun değiştirme maliyetinin beş boyutu üzerindeki olası etkileri incelenmiş̧ir. Bu etkiler Şekil 1'de yer alan araştırmanın teorik modelinde görülmektedir.

Şekil 1'de gösterilen araştırma modeline göre, bu araştırmada şikâyete yönelik tutumun iki boyutu olan kişisel ve sosyal şikâyet boyutlarının değiştirme maliyetinin parasal maliyet, belirsizlik maliyeti, öğrenme maliyeti, kurulum maliyeti ve ilişkisel maliyet boyutları üzerindeki beklenen negatif etkileri incelenecektir.

Şekil 1: Araştırmanın Modeli

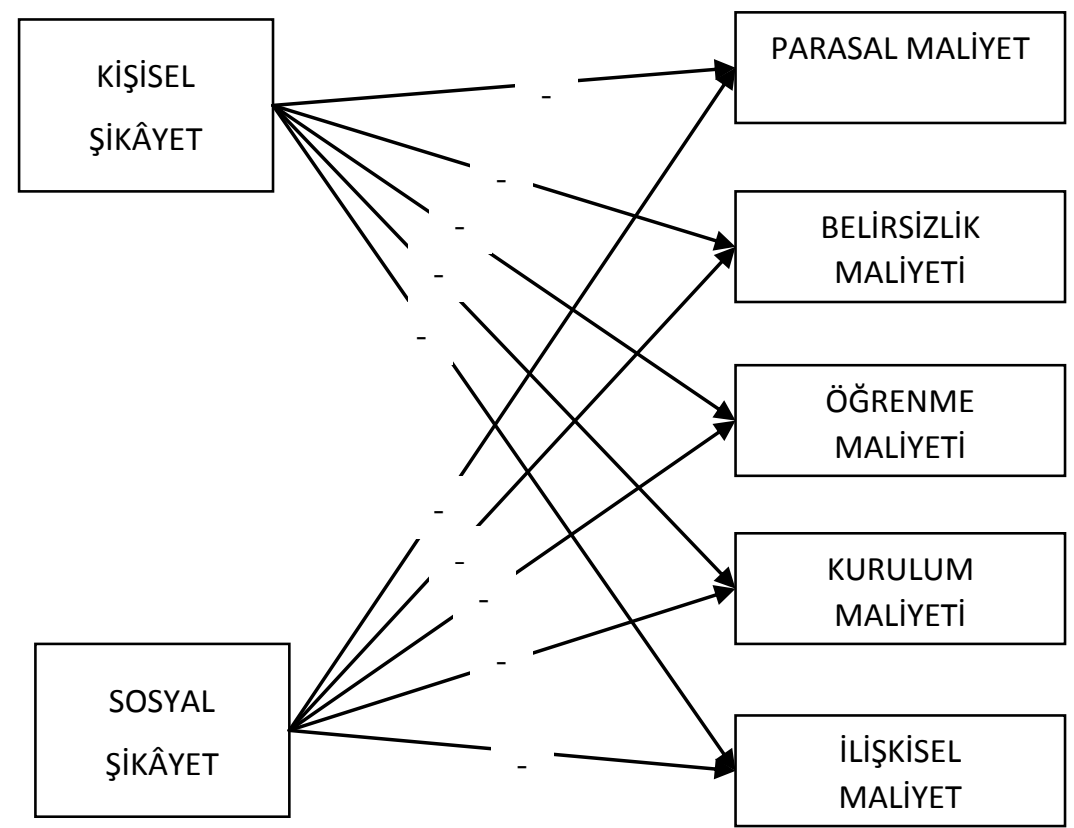

\subsection{Araştırmanın Evreni ve Örneklem}

Araştırmanın ana kütlesini, Manisa'nın Saruhanlı ilçesinde yaşayan ve herhangi bir bankanın müşterisi olan bireyler oluşturmaktadır. Araştırmanın saha çalışması, kolayda örnekleme yöntemiyle belirlenen 600 banka müşterisine araştırmanın anket formu gönderilerek başlamıştır. 2016 yılının Haziran ve Temmuz aylarında yürütülen saha çalışmasında 402 formun geri dönüşü sağlanmıştır. Bu anket formları içerisinden yanlış ya da eksik doldurulan, soruların tümünde ya da büyük bir kısmında aynı seçeneğin işaretlendiği ve okunmadan cevaplandığı anlaşılan 62 anket formu analiz kapsamına dâhil edilmemiştir. Bu işlemin ardından 340 anket verisi üzerinden gerekli analizler gerçekleştirilmiştir.

\subsection{Anket Formunun Tasarımı}

Araştırmanın anket formu oluşturulmadan önce, araştırma değişkenlerine yönelik detaylı bir literatür incelemesi yapılmıştır. Bu inceleme sonucunda uygun görülen ölçekler belirlenerek anket formu hazırlanmıştır. Söz konusu değişkenlere ait soruların geçerli olup olmadığını belirlemek için ve soruların anlaşılabilirliğiyle ilgili sorun ihtimaline karşıık, Manisa'nın 
Saruhanlı ilçesinde 200 banka müşterisinden elde edilen verilerle bir ön test çalışması gerçekleştirilmiştir. Ön test sonucunda anket formuna son hali verilmiş ve araştırmanın uygulama safhasına geçilmiştir.

Anket formu üç bölümden oluşmaktadır. A bölümünde cevaplayıcıların demografik özellikleri ve en sık kullandıkları banka sorulmuştur. B bölümünde değiştirme maliyeti boyutlarına ilişkin sorular yer almaktadır. $C$ bölümünde ise müşterilerin yazılı senaryoyu okumaları ve sık kullandıkları banka ile ilişkilendirip şikâyete yönelik tutum ifadelerini değerlendirmeleri istenmiştir.

Banka müşterilerinin yaşadığı tatminsizlik karşısındaki değerlendirmelerini doğrudan sorularla tespit etmek zor olabilir. Ayrıca, banka müşterileri şikâyet eğilimlerinde üçüncü şahısların eylemlerini değerlendirirken, daha rahat ve objektif olabilirler. Böylece, zihinlerinin arka planında yer alan değerlendirmeler, daha kolay ve doğru biçimde tespit edilebilir. Bu nedenlerle, araştırmada senaryo tekniğinin kullanılması uygun bulunmuştur. Diğer taraftan, senaryo kullanımı sosyal yapının standardize edilmesine ve senaryo ile eş zamanlı yanıt alındığından, daha gerçekçi sonuçların ortaya çıkmasına yardımcı olmaktadır (Özbek vd., 2013, s.117). Bu araştırmada kullanılan senaryo, Akkılıç ve arkadaşları (2010) tarafından hazırlanmış senaryolardan yararlanılarak oluşturulmuştur.

Anket formunda yer alan senaryo şöyledir;

“XYZ Bankası Türkiye'nin en büyük bankalarından biridir. Banka, kısa bir süre önce maaşlarını kendi bankalarından çeken müşterilere özel, düşük faizli bir kredi kampanyası hazırlamıştır. Bu kampanyanın reklamları televizyonlarda gösterildiğinde reklamı gören ve cazip faiz avantajını değerlendirmek isteyen Bay A, gerekli evrakları hazırlayarak bankanın bir şubesine başvurmuştur. Ancak bankada görüştüğü müşteri temsilcisi, Bay A'ya reklamlarda ve tanıtım afişlerinde belirtilmemiş olmasına rağmen bu kampanyadan yararlanabilmesi için bankanın kredi kartını alma zorunluluğunun bulunduğunu söylemiştir. Maddi sıkıntı içerisinde bulunan Bay A krediyi kullanabilmek için istemeyerek de olsa XYZ bankasının kredi kartını almak zorunda kalmışır."

Bu araştırmada şikâyete yönelik tutumun ölçümünde Ekiz ve Köker (2011) tarafından geliştirilen ölçekten yararlanılmıştır. Değiştirme maliyeti maddeleri ise Aydın (2005) tarafından geliştirilen değiştirme maliyeti ölçeği revize edilerek kullanılmıştır. Bu iki ölçeğin sorularının cevaplanmasında 5'li Likert yöntemi kullanılmıştır (1= Kesinlikle katılmıyorum; $2=$ Katılmıyorum; $3=$ Ne katılıyorum ne katılmıyorum; 4= Katılıyorum; 5= Kesinlikle katılıyorum)

\section{ARAŞTIRMANIN BULGULARI}

Bu bölümde araştırma verilerinin analizi sonucunda elde edilen bulgulara yer verilmiştir. Verilerin değerlendirilmesinde ve analizinde SPSS 16.0 ve AMOS 18.0 programları kullanılmıştır. Öngörülen modelin ve hipotezlerin test edilebilmesi için, öncelikle elde edilen veriler keşifsel ve doğrulayıc faktör analizi ile incelenmiştir. Ardından, yapısal eşitlik modellemesi kullanılarak araştırma hipotezleri test edilmiştir.

\subsection{Keşifsel ve Doğrulayıcı Faktör Analizi Bulguları}

Tablo 1'de şikâyete yönelik tutumun alt boyutlarını ortaya koymaya yönelik olarak yapılan keşifsel faktör analizi sonuçları görülmektedir. Faktör analizi işlemi yapılmadan önce, verilerin faktör analizine uygun olup olmadığını ve örneklem büyüklüğünün faktör analizi için yeterli olup olmadığını belirlemek amacıyla hesaplanan KMO (Kaiser-Meyer-Olkin) değeri 0,852 olarak bulunmuştur. KMO testi değerinin 0,6'dan büyük olması önerilmektedir (İslamoğlu ve Alnıaçık, 2014, s.396). Bu analizden sonra, ana kütle içindeki değişkenler arasında bir ilişkinin var olup olmadığını belirlemek amacıyla Bartlett'ın Küresellik Testi sonuçları incelenmiştir. Faktör analizinin uygulanabilmesi için bu testin sonucunun anlamlı çıkması $(p<0,05)$ istenmektedir (İslamoğlu ve Alnıaçık, 2014, s.396). Bu test değerinin anlamlı çıkması ilişkinin varlığını ve bu verinin faktör analizi yapmak için uygun olduğunu göstermektedir (Nakip, 2006, s.428- 429). Bu araştırma özelinde Bartlett'ın Küresellik Testi'nin anlamlılık düzeyi 0,001 olarak hesaplanmıştır.

\section{Tablo 1: Şikâyete Yönelik Tutuma iliş̧kin Keşifsel Faktör Analizi Sonuçları}

\begin{tabular}{|c|c|c|}
\hline ŞİKÂYETE YÖNELIK TUTUM & 1 & 2 \\
\hline \multicolumn{3}{|l|}{ KişiSEL ŞiKÂYET } \\
\hline İlk fırsatta ilgili bir yöneticiye şikâyette bulunurum. & 0,736 & \\
\hline Bu bankanın hizmetlerini bir daha kullanmamaya karar veririm. & 0,746 & \\
\hline Bu kötü tecrübem hakkında arkadaşlarımla ve akrabalarımla konuşurum. & 0,737 & \\
\hline Hemen müşteri hizmetlerini arar ve problemimle ilgilenmelerini isterim. & 0,647 & \\
\hline \multicolumn{3}{|l|}{ SOSYAL ŞIKAYET } \\
\hline Firmaya karşı yasal girişimlerde bulunarak hakkımı ararım. & & 0,805 \\
\hline Diğer müşterileri uyarmaları için olayı bir tüketici derneğine bildiririm. & & 0,817 \\
\hline $\begin{array}{l}\text { Bir tüketici derneğine şikâyette bulunur ve bankanın problemimle ilgilenmesini sağlamalarını } \\
\text { isterim. }\end{array}$ & & 0,638 \\
\hline Yaşadığım bu kötü deneyimi sosyal medyada paylaşırım. & & 0,608 \\
\hline
\end{tabular}




\begin{tabular}{|l|c|c|} 
ÖZ DEĞER & 3,515 & 1,105 \\
\hline AÇIKLANAN VARYANS (\%) & 43,933 & 13,816 \\
\hline TOPLAM AÇIKLANAN VARYANS (\%) & 57,749 \\
\hline
\end{tabular}

Tablo 1'deki bulgular, şikâyete yönelik tutum değişkeninin alt boyutlarının beklendiği gibi ayrıştığını ve maddelerin ilgili faktörlere yüklendiğini göstermektedir. Keşifsel faktör analizi sonucunda açıklanan varyans değeri \%57,749 olarak hesaplanmıştır. Ayrıca tüm boyutlara ilişkin faktör yüklerinin kritik eşiğin üzerinde olduğu görülmektedir $(\geq 0,55)$.

Tablo 2'de değiştirme maliyeti değişkeninin alt boyutlarını ortaya koymaya yönelik olarak yapılan keşifsel faktör analizi sonuçları görülmektedir. Bu analiz öncesinde KMO değeri 0,792 ve Bartlett'ın Küresellik Testi'nin anlamlılık düzeyi 0,001 olarak hesaplanmıştır. Bu değerler, örnek büyüklüğünün faktör analizi yapmak için yeterli olduğunu ve verinin bu analize uygun olduğunu göstermektedir.

Tablo 2'deki bulgular, değiştirme maliyeti değişkeninin alt boyutlarının beklendiği gibi ayrıştığını ve maddelerin ilgili faktörlere yüklendiğini göstermektedir. Keşifsel faktör analizi sonucunda açıklanan varyans değeri \%63,473 olarak hesaplanmıştır. Ayrıca faktör yüklerinin kritik değerin üzerinde olduğu görülmektedir.

Tablo 2: Değiştirme Maliyetine iliş̧kin Keşifsel Faktör Analizi Sonuçları

\begin{tabular}{|c|c|c|c|c|c|}
\hline DEĞişTiRME MALIYETi & 1 & 2 & 3 & 4 & 5 \\
\hline \multicolumn{6}{|l|}{ PARASAL DEĞiŞTiRME MALIYETi } \\
\hline $\begin{array}{l}\text { Kullandığım bankayı yeni bir bankayla değiştirmenin maliyeti } \\
\text { olacaktır. }\end{array}$ & 0,819 & & & & \\
\hline Mevcut bankamı değiştirmemin parasal maliyeti vardır. & 0,827 & & & & \\
\hline Banka değiştirmenin parasal maliyeti benim için yüksektir. & 0,736 & & & & \\
\hline $\begin{array}{l}\text { Mevcut bankamı değiştirmenin parasal maliyeti benim için } \\
\text { önemlidir. }\end{array}$ & 0,615 & & & & \\
\hline \multicolumn{6}{|l|}{ BELIRSIZLIK MALIYETi } \\
\hline $\begin{array}{l}\text { Bankamı değiştirdiğimde, yeni bankamın sunduğu hizmet } \\
\text { beklediğim gibi olmayabilir. }\end{array}$ & & 0,796 & & & \\
\hline $\begin{array}{l}\text { Bankamı değiştirdiğimde, kısa süre de olsa yetersiz hizmetle } \\
\text { karşılaşabilirim. }\end{array}$ & & 0,733 & & & \\
\hline $\begin{array}{l}\text { Bankamı değiştirirsem, şu anki bankamdan kazandığım birtakım } \\
\text { imkânları (faiz indirimi, hediye para puanlar, indirimli havale ücreti } \\
\text { gibi) kaybederim. }\end{array}$ & & 0,609 & & & \\
\hline $\begin{array}{l}\text { Yeni bankanın bana sunduklarının daha avantajlı olacağından emin } \\
\text { olamam. }\end{array}$ & & 0,630 & & & \\
\hline \multicolumn{6}{|l|}{ ÖĞRENME MALIYETi } \\
\hline $\begin{array}{l}\text { Yeni bankamın sunduğu bazı hizmetleri hızlı bir şekilde } \\
\text { kullanabilmem için belli bir süre gerekebilir. }\end{array}$ & & & 0,820 & & \\
\hline $\begin{array}{l}\text { Bankamı değiştirdiğimde kullanımını öğreninceye kadar bazı } \\
\text { hizmetlerden yararlanamayabilirim. }\end{array}$ & & & 0,769 & & \\
\hline $\begin{array}{l}\text { Yeni bankamın sunduğu hizmetlerden tam olarak yararlanabilmem } \\
\text { için geçecek süre benim için önemlidir. }\end{array}$ & & & 0,649 & & \\
\hline \multicolumn{6}{|l|}{ KURULUM MALIYETI } \\
\hline $\begin{array}{l}\text { Eski banka hesap numaramı bilenlerin bana ulaşamayacak olması } \\
\text { beni düşündürmektedir. }\end{array}$ & & & & 0,855 & \\
\hline Yeni hesap numaramı çevremdeki insanlara bildirmek zor olacaktır. & & & & 0,828 & \\
\hline \multicolumn{6}{|l|}{ İLiŞKISEL MALIYET } \\
\hline Mevcut bankam hakkında olumlu şeyler düşünüyorum. & & & & & 0,808 \\
\hline Benim için bankanın ismi (markası) de önemlidir. & & & & & 0,794 \\
\hline $\begin{array}{l}\text { Benim için bankamın güvenilir (fiyatlandırma, hizmet kalitesi vb. } \\
\text { faktörleri göz önüne aldığımda) olması da önemlidir. }\end{array}$ & & & & & 0,713 \\
\hline ÖZ DEĞER & 4,352 & 1,898 & 1,235 & 1,185 & 1,486 \\
\hline AÇIKLANAN VARYANS (\%) & 27,200 & 11,860 & 7,716 & 7,409 & 9,287 \\
\hline TOPLAM AÇIKLANAN VARYANS (\%) & & & 63,473 & & \\
\hline
\end{tabular}

Araştırmada kullanılan ölçeklerin boyutları Keşifsel Faktör Analizi ile belirlenmiştir. Ancak, araştırma soruları genel olarak yabancı dilde yazılmış kaynaklardan ya da farklı çalışmalardan alındığı için bu uygulamada ölçeğin doğrulanması 
gerekmektedir. Bu nedenle, Doğrulayıcı Faktör Analizi'nin (DFA) yapılması gerekli görülmüştür. AMOS 18.0 paket programıyla gerçekleştirilen analiz sonucunda araştırma sorularının ilgili faktörlere yüksek faktör yükleri ile yüklendiği görülmüştür (0,56-0,86 arasında). Uyum iyiliği indeksleri incelendiğinde $X^{2} /$ sd değeri 1,744 olarak bulunmuştur. Bu değer, veri uyumunun iyi olduğunu göstermektedir. Ayrıca Tablo 3'te görüldüğü gibi hesaplanan RMSEA değeri $(0,047)$ faktör yapısının iyi uyumuna işaret etmekte; $\operatorname{SRMR}(0,0575)$, AGFI $(0,890)$, ve GFI $(0,917)$ değerleri ise kabul edilebilir uyum göstermektedir. NFI $(0,854)$ ve CFI $(0,931)$ değerleri ise kabul edilebilir uyum değerlerinin bir miktar altında kalmıştır. Hiçbir modifikasyon yapılmadan ortaya çıkan bu değerler, verinin kabul edilebilir bir uyuma sahip olduğunu söylemek için yeterli görülmüştür.

Tablo 3: DFA Uyum İyiliği İndeksleri

\begin{tabular}{|c|c|c|c|}
\hline Uyum Ölçüleri & İyi Uyum & Kabul Edilebilir Uyum & $\begin{array}{c}\text { Araştırmada Ortaya } \\
\text { Çıkan Değer }\end{array}$ \\
\hline SRMR & $0 \leq \mathrm{SRMR} \leq 0,05$ & $0,05 \leq \mathrm{SRMR} \leq 0,10$ & 0,0575 \\
\hline GFI & $0,95 \leq \mathrm{GFI} \leq 1,00$ & $0,90 \leq \mathrm{GFI}<0,95$ & 0,917 \\
\hline AGFI & $0,90 \leq \mathrm{AGFI} \leq 1,00$ & $0,85 \leq \mathrm{AGFI}<0,90$ & 0,890 \\
\hline NFI & $0,95 \leq \mathrm{NFI} \leq 1,00$ & $0,90 \leq \mathrm{NFI}<0,95$ & 0,854 \\
\hline CFI & $0,97 \leq \mathrm{CFI} \leq 1,00$ & $0,95 \leq \mathrm{CFI}<0,97$ & 0,931 \\
\hline RMSEA & $0 \leq \mathrm{RMSEA} \leq 0,05$ & $0,05<\mathrm{RMSEA} \leq 0,08$ & 0,047 \\
\hline
\end{tabular}

Kaynak: Bayram, N. (2010). Yapısal eşitlik modellemesine giriş: AMOS uygulamaları. (1). Bursa. Ezgi Kitabevi.

\subsection{Güvenilirlik Analizi Bulguları}

Araştırma sorularının güvenilirliğini ölçmek amacıyla Likert ölçeği ile gerçekleştirilen çalışmalarda yaygın bir biçimde kullanılan Cronbach'ın Alfa Katsayısı kullanılmıştır. Tablo 4'te görüldüğü gibi tüm boyutların güvenilirlik katsayısı kritik değer olarak kabul edilen 0,70 ve üzerinde değerler almıştır. Tüm soruların birlikte değerlendirildiği analizler sonucunda, şikâyete yönelik tutuma ilişkin Cronbach'ın Alfa Katsayısı 0,815; değiştirme maliyetine ilişkin Cronbach'ın Alfa Katsayısı 0,813 olarak hesaplanmıştır. Bu sonuçlar araştırma ölçeklerinin güvenilir olduğunu göstermektedir (Nakip, 2006, s.145).

Tablo 4: Güvenilirlik Analizi Bulguları

\begin{tabular}{|l|c|c|}
\hline Boyutlar / Ölçekler & $\begin{array}{c}\text { Madde } \\
\text { Sayısı }\end{array}$ & $\begin{array}{c}\text { Cronbach } \boldsymbol{\alpha} \\
\text { Katsayısı }\end{array}$ \\
\hline Şikâyete Yönelik Tutum & 8 & 0,815 \\
\hline Kişisel Şikâyet & 4 & 0,741 \\
\hline Sosyal Şikâyet & 4 & 0,753 \\
\hline Değiştirme Maliyeti & 16 & 0,813 \\
\hline Parasal Maliyet & 4 & 0,773 \\
\hline Belirsizlik Maliyeti & 4 & 0,701 \\
\hline Öğrenme Maliyeti & 3 & 0,709 \\
\hline Kurulum Maliyeti & 2 & - \\
\hline ilişsisel Maliyet & 3 & 0,739 \\
\hline
\end{tabular}

\subsection{Araştırmanın Tanımlayıcı İstatistikleri}

Araştırmaya katılan cevaplayıcıların cinsiyetleri incelendiğinde, \%48,5'inin kadın ( $n=165), \% 51,5^{\prime}$ inin ise erkek ( $\left.n=175\right)$ banka müşterilerinden oluştuğu görülmektedir. Araştırmaya katılan cevaplayıcıların medeni hallerine göre dağılımı \%43,5 ( $n=148)$ bekar, \%56,5 ( $n=192)$ ise evli şeklinde ortaya çıkmıştır. Cevaplayıcıların \%7,4'ü $(n=25)$ ilkokul, \%33,8'i $(n=115)$ ortaokul, \%55'i ( $n=187)$ üniversite ve \%3,8'i ( $n=13$ ) lisansüstü eğitim mezunu olduğunu ifade etmiştir. Araştırmaya katılan cevaplayıcıların \%26,8'i ( $n=91$ ) İş Bankası, \%22,9'u ( $n=78$ ) Akbank, \%19,1'i ( $n=65)$ Ziraat Bankası, \%7,7'si ( $n=26$ ) Garanti Bankası ve \%3,2'si $(n=11)$ Denizbank ve Finansbank müşterisi olduğu saptanmıştır. Diğer bankaların müşterisi olduğunu ifade eden cevaplayıcıların oranı ise \%17,1 $(n=58)$ olarak hesaplanmıştır. Katılımcıların yaşlarının aritmetik ortalaması 33,51 iken, hane halkı toplam gelirlerinin ortalaması 3523,30 TL olarak hesaplanmıştır. Tablo 5'te araştırmanın ana değişkenlerine ilişkin istatistikler yer almaktadır.

Tablo 5: Araştırmanın Ana Değişkenlerine ilişkin İstatistikler

\begin{tabular}{|l|c|c|c|c|c|c|c|}
\hline & KS & SS & PM & BM & OM & KM & IM \\
\hline Aritmetik Ortalama & 3,31 & 3,30 & 2,88 & 3,25 & 3,41 & 3,04 & 3,59 \\
\hline Standart Sapma & 0,790 & 0,911 & 0,960 & 0,835 & 1,115 & 0,888 & 0,961 \\
\hline
\end{tabular}


KS: Kişisel Şikâyet; SS: Sosyal Şikâyet; PM: Parasal Maliyet; BM: Belirsizlik Maliyeti; OM:

Öğrenme Maliyeti; KM: Kurulum Maliyeti; IM: Ilişkisel Maliyet

Tablo 5'te yer alan bulgulara göre, şikâyete yönelik tutum ölçeğinin kişisel şikâyet ve sosyal şikâyet boyutlarına verilen cevapların aritmetik ortalaması sırasıyla 3,31 ve 3,30 olarak hesaplanmıştır. Bu sonuç, araştırmada yer alan senaryoya bağlı olarak, cevaplayıcıların ortalamanın üzerinde bir şikâyet tutumu sergileyeceğini göstermektedir. Değiştirme maliyetine verilen cevapların ortalamaları incelendiğinde ise, cevaplayıcılar banka değiştirme konusunda en yüksek maliyetlerin ilişkisel maliyet $(A O=3,59)$ ve öğrenme maliyeti $(A O=3,41)$ olduğunu; parasal maliyet $(A O=2,88)$ ve kurulum maliyetinin $(A O=3,04)$ ise en düşük maliyetler olduğunu ifade etmiştir.

\subsection{Hipotezlerin Testi}

Tablo 6'da araştırma hipotezlerinin yapısal eşitlik modeli ile test edilmesi ile ortaya çıkan bulgular yer almaktadır.

Tablo 6: Yapısal Eşitlik Modeli ile Hipotezlerin Test Sonuçları

\begin{tabular}{|c|c|c|c|c|c|c|}
\hline Hipotezler & Bağımsız Değişken & Bağımlı Değişken & Standardize & $\boldsymbol{\beta}$ & $\mathbf{t}$ & Sonuçlar \\
\hline H1 & Kişisel Şikâyet & Parasal Maliyet & $-0,228$ & $-3,805$ & 0,001 & Desteklendi \\
\hline H2 & Kişisel Şikâyet & Belirsizlik Maliyeti & $-0,282$ & $-4,816$ & 0,001 & Desteklendi \\
\hline H3 & Kişisel Şikâyet & Öğrenme Maliyeti & $-0,260$ & $-4,453$ & 0,001 & Desteklendi \\
\hline H4 & Kişisel Şikâyet & Kurulum Maliyeti & $-0,008$ & $-0,138$ & 0,890 & Desteklenmedi \\
\hline H5 & Kişisel Şikâyet & Ilişkisel Maliyet & $-0,221$ & $-3,695$ & 0,001 & Desteklendi \\
\hline H6 & Sosyal Şikâyet & Parasal Maliyet & $-0,095$ & $-1,581$ & 0,114 & Desteklenmedi \\
\hline H7 & Sosyal Şikâyet & Belirsizlik Maliyeti & $-0,114$ & $-1,948$ & 0,051 & Desteklendi \\
\hline H8 & Sosyal Şikâyet & Öğrenme Maliyeti & $-0,157$ & $-2,701$ & 0,007 & Desteklendi \\
\hline H9 & Sosyal Şikâyet & Kurulum Maliyeti & $-0,203$ & $-3,321$ & 0,001 & Desteklendi \\
\hline H10 & Sosyal Şikâyet & Ilişkisel Maliyet & $-0,124$ & $-2,083$ & 0,037 & Desteklendi \\
\hline
\end{tabular}

Tablo 6'da yer alan araştırma hipotezlerinin test sonuçları incelendiğinde, araştırmanın H4 ve H6 dışında kalan 8 hipotezinin desteklendiği görülmektedir. Buna göre, şikâyete yönelik tutum değişkeninin kişisel şikâyet boyutunun, değiştirme maliyetinin parasal maliyet, belirsizlik maliyeti, öğrenme maliyeti ve ilişkisel maliyet boyutları üzerinde negatif etkisi olduğu söylenebilir. Bu etkilerin en yükseği öğrenme maliyetinde gerçekleşmiştir $(\beta=-0,260)$. Öte yandan, kişisel şikâyetin kurulum maliyeti üzerinde anlamlı bir etkisi saptanamamıştır. Şikâyete yönelik tutum değişkeninin sosyal şikâyet boyutunun, değiştirme maliyetinin belirsizlik maliyeti, öğrenme maliyeti, kurulum maliyeti ve ilişkisel maliyet boyutları üzerinde negatif etkileri tespit edilmiştir. Sosyal şikâyetin en yüksek etkisi ise kurulum maliyetinde ortaya çıkmıştır $(\beta=-0,203)$. Diğer taraftan, sosyal şikâyetin parasal maliyet üzerinde herhangi bir etkisi saptanamamıştır.

\section{SONUÇ VE ÖNERILER}

Bu araştırma banka müşterilerinin şikâyete yönelik tutumlarının değiştirme maliyeti üzerindeki olası etkilerini tespit etmek amacıyla gerçekleştirilmiştir. Araştırma bulguları beklenen negatif etkileri destekler niteliktedir. Bu sonuç genel bir ifadeyle, banka müşterilerinin kişisel şikâyet ya da sosyal şikâyet tutumu sergilemeleri halinde değiştirme maliyeti algılarının azaldığını; yani şikâyet tutumu sergileyen müşterilerin, kullandığı bankayı değiştirmek istediğini göstermektedir.

Bulgular ayrıntılı olarak değerlendirildiğinde, banka müşterilerinin kişisel şikâyet tutumlarının değiştirme maliyetinin parasal maliyet boyutu üzerinde anlamlı bir etkisi olduğu görülmektedir. Bu sonuç, müşterilerin kişisel şikâyet tutumları arttıkça parasal maliyet algılarının azaldığını göstermektedir. Diğer bir deyişle, müşteriler kişisel şikâyet tutumuna neden olacak bir eylemle karşılaştığında, parasal kayıptan kaynaklanan firmayı değiştirme korkularında bir azalma gerçekleşmektedir. Benzer şekilde, müşterilerin kişisel şikâyet tutumlarının artması belirsizlik, öğrenme ve ilişkisel maliyetlerinin azalmasına sebep olmaktadır. Ancak müşterilerin kişisel şikâyetlerinin kurulum maliyeti üzerinde beklenen negatif etkisi saptanamamıştır. Dolayısıyla, kişisel şikâyete neden olan bir eylemin gerçekleşmesi, müşterinin firma değiştirmeye yönelik kurulum maliyeti endişesini azaltmamaktadır. Sonuç itibariyle, müşterilerin şikâyete konu olabilecek bir durum ile karşılaşmaları halinde, şikâyetlerini eş-dost, akraba gibi yakın çevresiyle paylaşmaları, firmayı değiştirmeye yönelik parasal, belirsizlik, öğrenme ve ilişkisel maliyet algılarını azaltacağı için mevcut bankanın değiştirilme ihtimali artacaktır.

Benzer sonuçlar sosyal şikâyete yönelik tutumların değiştirme maliyeti üzerindeki etkisinde de gerçekleşmiştir. Araştırma bulguları, sosyal şikâyet tutumu arttıkça, belirsizlik maliyeti, öğrenme maliyeti, kurulum maliyeti ve ilişkisel maliyet algısının azalacağını göstermektedir. Diğer taraftan, sosyal şikâyet algısının parasal maliyet üzerinde anlamlı bir etkisi saptanamamıştır. Bu sonuçlar, banka müşterilerinin en sık kullandıkları bankayı, sosyal şikâyete (sosyal medya ve tüketici derneklerine şikâyet gibi) yönelik tutum oluşturabilecek bir sorunla karşılaştıklarında terk edebileceklerini göstermesi 
bakımından önemlidir. Bu durum şüphesiz bankaların karşılaşmak istemeyeceği bir sorundur. Tüm bu sonuçlardan hareketle bankaların, müşterilerini elde tutabilmesi için onların değiştirme maliyeti algısını artırmaya çalışması gereklidir.

Bu araştırmada Ekiz ve Köker (2011) tarafından geliştirilen şikâyete yönelik tutum ölçeği kullanılmıştır. Literatürde psikolojik şikâyet tutumundan da bahsedilmektedir (Ekiz ve Köker, 2010). Şikâyete yönelik tutum ölçeğine psikolojik şikâyet boyutu da eklenerek bir çalışma yapılabilir. Yine bu araştırma, zaman ve maliyet kısıtından dolayı Manisa'nın Saruhanlı ilçesinde gerçekleştirilmiştir. İleride yapılacak çalışmalar daha büyük bir örneklemle gerçekleştirilebilir. Bu araştırmada bankaların şikâyete konu olan sorunları çözmeleri, yani hizmet hatalarını telafi etmeleri halinde ne gibi sonuçların ortaya çıkacağı da incelenmemiştir. Bu araştırmanın belki de en büyük eksikliği budur. Bu nedenle, benzer bir araştırma yapacak olan akademisyenlere, çalışmalarında hizmet hatasının telafi edildiği ve edilmediği iki farklı senaryo kullanarak karşılaştırma yapmaları önerisinde bulunulabilir. Literatürde şikâyete yönelik tutumlar ile kültür arasındaki ilişkilerin incelendiği pek çok çalışma bulunmaktadır. Bu araştırmanın modeli kullanılarak kültürlerarası farklılıkları ortaya koymaya yönelik bir araştırma yapılabilir.

\section{KAYNAKLAR}

Akkılıç, M.E., Özbek, V., Koç, F. (2010). Banka reklamlarında eksik bilgi sunumunun pazarlama etiği açısından değerlendirilmesi. 15. Ulusal Pazarlama Kongresi Bildiriler Kitabı, Kuşadası, p. 386-397.

Aydın, S. (2005). Türk GSM sektöründe müşteri sadakatinin belirleyicileri ve değiştirme maliyeti arasındaki ilişkilerin analizi. Yayımlanmamış Doktora Tezi, Gebze Yüksek Teknoloji Enstitüsü, Sosyal Bilimler Enstitüsü, İşletme Anabilim Dalı, Gebze.

Bozkaya, A.T. (2012). Bankacılık sektöründe hizmet hatası ve hizmet telafisi. Yayımlanmamış Yüksek Lisans Tezi, Balıkesir Üniversitesi, Sosyal Bilimler Enstitüsü, İşletme Anabilim Dalı, Balıkesir.

Burucuoğlu, M. (2011). Müşteri memnuniyeti ve sadakati arttırmada müşteri şikâyetleri yönetiminin etkinliği: Bir örnek olay incelemesi. Yayımlanmamış Yüksek Lisans Tezi, Karamanoğlu Mehmetbey Üniversitesi, Sosyal Bilimler Enstitüsü, İşletme Anabilim Dalı, Kahramanmaraş.

Crie, D. (2003). Consumers' complaint behavior taxonomy, typology and determinants: Towards a unified ontology. Database Marketing \& Customer Strategy Management, vol. 11, no.1, p. 60-79.

Çankaya F., Çilingir, Z. (2008). Hizmet sadakatinin geliştirilmesinde bir fayda maliyet yaklaşımı: Bankacılık sektörü üzerinde bir uygulama. Anadolu Üniversitesi Sosyal Bilimler Dergisi, vol.8, no.1, p. 25-46.

Day, R., Landon, L. (1977). Toward a theory of consumer complaining behavior. Consumer and Industrial Buying Behavior, p. $427-437$.

Ekiz, H.E., Köker, E.N. (2010). Şikâyetin kısıtlayıcı faktörleri: Turistlerin belirgin şikâyet etme davranışları. Journal of Yasar University, vol.17, no.5, p. 2859-2873.

Ekiz, H.E., Köker, E.N. (2011). Şikâyet etmeye yönelik tavırların sadakat üzerindeki etkileri: Çin ve amerikan bakış açılarının karşılaştırılması. İşletme Araştırmaları Dergisi, vol.3, no.4, p. 80-103.

Erdoğan Z., Torun, T. (2009). Bir bilişsel pazarlama aracı olarak sosyal topluluklar. Pazarlama ve Pazarlama Araştırmaları Dergisi, no.4, p. 4171.

Eşkinat, A. (2009). Müşterilerin elde tutulmasında şikâyet yönetimi ve hizmet sektörüne ilişkin bir uygulama. Yayımlanmamış Doktora Tezi, Marmara Üniversitesi, Sosyal Bilimler Enstitüsü, İstanbul.

Filip A.E.A. (2009). Customer loyalty and its determinants in a banking service environment. Amfitreatru Economic, vol.11, no.26, p. 288297.

Guiltinan, J.P. (1989). A classification of switching costs with implications for relationship marketing. AMA Winter Educators' Conference Proceedings, Chicago, p. 216-220.

Hirschman A.O. (1970). Exit, voice and loyalty responses to decline in firms, organizations and states. Harvard University Press, Cambridge.

İslamoğlu, A.H., Alnıaçık, Ü. (2014). Sosyal Bilimlerde Araştırma Yöntemleri. (4), Beta Yayın Dağıtım: İstanbul.

Jackson, B.B. (1985). Winning and keeping industrial customers: The dynamics of customer relationships. Lexington, MA, Lexington Books.

Jacoby, J., Jaccard, J.J. (1981). The sources, meaning, and validity of consumer complaint behavior: A psychological analysis. Journal of Retailing, no.57, p. 4-24.

Jones, M.A., Beatty, S.E., Mothersbaugh, D.V. (2002). Why customer stay: Measuring the underlying dimensions of services switching cost and managing their differential strategic outcomes. Journal of Service Industry Management, vol.12, no.2, p. 90-120.

Karaca, Ş. (2010). Hizmet sektöründe ilişki pazarlaması. Selçuk Üniversitesi Sosyal Ekonomik Araştırmalar Dergisi, no.19, p. 441-445.

Klemperer, P. (1995). Competition when consumers have switching costs: An overviev with aplications to industrial organization, macroecomics and international trade. Review of Economic Studies, no.62, p. 515- 539. 
Koç, F. Şahin, N.K., Özbek, V. (2014). Hizmet hataları ve algılanan kalite arasındaki ilişki üzerinde değiştirme maliyetinin aracılık etkisi: Küçük işletmeler ve hizmet satın aldıkları muhasebecilere yönelik bir uygulama. Pazarlama ve Pazarlama Araştırmaları Dergisi, no.14, p. 21-46.

Lee, M., Cunningham, L.F. (2001). A cost/benefit approach to understanding service loyalty. Journal of Services Marketing, vol.15, no.2, p. 113-130.

Lovelock, C.H., Lauren K.W. (1999). Principles of services marketing and management. Prentice Hall, New Jersey.

Nakip, M. (2006). Pazarlama araştırmaları teknikler ve SPSS destekli uygulamalar. Ankara: Seçkin Yayıncılık.

Özbek, V., Özer, G., Aydın, K. (2013). İşletme öğrencilerinin dindarlık düzeyleri ve etik niyetlerinin pazarlama etiği bağlamında değerlendirilmesi. Business and Economics Research Journal, vol.4, no.3, p. 11-129.

Özer, G., Aydın S. (2004). GSM sektöründe müşteri sadakati, memnuniyet, değiştirme maliyeti ve güven arasındaki ilişki. İktisadi ve İdari Bilimler Dergisi, vol.18, no.3-4, p. 157-179.

Porter, M.E. (2007). Rekabet stratejisi: Sektör ve rakip analizi teknikleri (Çev: Gülen Ulubilgen). İstanbul: Sistem Yayıncılık.

Richins, M.L. (1983). Negative word of mouth by dissatisfied consumers: A pilot study. Journal Of Marketing, vol.47, no.1, p. 68-78.

Ruyter, K., Wetzels, M. (1998). On the relationship between perceived service quality, service loyalty and switching costs. International Journal of Service Industry Management, vol.9, no.5, p. 436-453.

Sarı, E. (2008). Müşteri şikâyet yönetiminin müşteri bakış açısıyla değerlendirilmesi ve TCDD 3. bölge müdürlüğünde bir uygulama. Yayımlanmamış Yüksek Lisans Tezi, Dumlupınar Sosyal Bilimler Enstitüsü, İ̧̧letme Anabilim Dalı, Kütahya.

Sharma, N., Patterson, P.G. (2000). Switching costs, alternative attractiveness and experience as moderators of relationship commitment in professional, consumer services. International Journal of Service Industry Management, vol.11, no.5, p. $470-490$.

Singh, J. (1988). Consumer complaint intentions and behavior: Definitional and taxonomical issues. Journal of Marketing, no.52, p. 93-107.

Şensöz, U. (2010). ISO 10002 müşteri memnuniyeti ve müşteri şikâyetleri yönetimi standardı ve müşteri memnuniyeti. Yayımlanmamış Yüksek Lisans Tezi, İstanbul Sosyal Bilimler Enstitüsü, İşletme Anabilim Dalı, İşletme Yönetimi ve Organizasyon Bilim Dalı, İstanbul.

Şimşek, G.G., Noyan, F. (2009). Türkiye'de cep telefonu cihazı pazarında marka sadakati için bir model incelemesi. ODTÜ Geliştirme Dergisi, no.36, p. 121-159.

Yılmaz, V., Şen, R. (2004). Lisrel ile yapısal eşitlik modelleri: Tüketici şikâyetlerine uygulanması. Sosyal Bilimler Dergisi, no.1, p. 77-90.

Zeithaml, V.A., Berry, L.L., Parasuraman, A. (1996). The behavioral consequences of service quality. Journal of Marketing, vol.60, no.2, p. 31-46. 